\title{
Chapter 2 \\ Toward a Framework for a Dialectical Relationship Between Pedagogical Practice and Research
}

\author{
Jussara de Loiola Araújo
}

\begin{abstract}
In this chapter, I present initial steps towards a framework for a dialectical relationship between pedagogical practice and research in the field of modelling in mathematics education. These methodological reflections have arisen from the development of research on modelling guided by critical mathematics education, and are grounded in a socio-political perspective of research. I will develop the idea that pedagogical practice and research should be seen as part of a single unit, mutually developing and influencing each other; that they are different, have different purposes, and may be incompatible, but one presupposes and constitutes the other. When a pedagogical practice is taking place at the same time as a research study, the researcher can have a double role, as a researcher and as a teacher, and the participants of the research can also have the role of students, in that pedagogical practice.
\end{abstract}

Keywords Pedagogical practice of modelling - Socio-political research •

Dialectic $\cdot$ Critical mathematics education

\subsection{Introduction: Setting the Scene and Presenting the Objective}

Mathematical modelling as an endeavour in mathematics teaching and learning gained more strength in the 1960s. However, according to Niss et al. (2007), it was just after the 1990s that mathematical modelling in mathematics education, as a field of research, reached what the authors call its "maturation phase", in which empirical studies started to be developed. In that period, the community became more organised with the foundation of the International Community of Teachers of Mathematical Modelling and Applications (ICTMA) and its affiliation as a Study Group of the International Commission on Mathematical Instruction (ICMI), in 2004. The

\footnotetext{
J. de Loiola Araújo (凶)

Department of Mathematics, Universidade Federal de Minas Gerais (UFMG), Belo Horizonte,

MG 31.270-901, Brazil

e-mail: jussara@mat.ufmg.br

(C) The Author(s) 2019 
authors claim that the ICMI Study Volume (Blum et al. 2007) "might be said to formally mark the maturation of applications and modelling as a research discipline in the field of mathematics education" (Niss et al. 2007, p. 29).

This very short summary of its history shows that the research field of modelling in mathematics education is relatively young. One characteristic of the maturation phase of the field is the growth of the amount of research being developed. A natural consequence is the emergence of studies aiming at understanding the nature of the research being developed in the field. Questions such as: "What are the research studies about?" or "How have the designs of research studies been characterized?" are more and more common. Examples of these kinds of studies can be found in the international literature (e.g., Geiger and Frejd 2015) as well as in the Brazilian literature (e.g., special issue of Revista Eletrônica de Educação Matemática ${ }^{1}$ ).

In this sense, the inspiration for this chapter is a particular overview of the research studies being developed in the young field of modelling in mathematics education. As a member of ICTMA and of the Brazilian community of mathematical modelling in mathematics education, I have observed that it has been common for research to be conducted in a context in which a pedagogical practice takes place at the same time. We can find reports of the simultaneous occurrence of pedagogical practice and research, for example, in the volumes of the ICTMA book series (e.g., Villarreal et al. 2015), or in academic journals (e.g., Albarracín and Gorgorió 2015).

A clear example of this situation can be found in the work of Schwarzkopf (2007). The author presents results of an empirical study guided by the following question: "How can we describe from a theoretical point of view the interplay between the realworld and mathematics, realised in everyday mathematics classroom interaction?" (p. 210). The study followed an interpretative research paradigm and data were gathered from "regular mathematics lessons of a fourth grade class of primary school (10 year old) students in Germany" (p. 211), where students were involved in the search for solutions to a modelling task and the teacher was the mediator of the discussion. The activity performed by students and teacher in the mathematics lesson is an example of what I call a pedagogical practice (see Sect. 2.2). It is the context of the research developed by Schwarzkopf (2007). The researcher depicted two episodes from the pedagogical practice as data to be analysed with the support of the theoretical framework in which the research was grounded.

Sometimes, the distinction between pedagogical practice and research in the literature of modelling in mathematics education is not so clear. In Swan et al. (2007)'s work, for example, the intention was to "illustrate how modelling promotes the learning of mathematics." (p. 276). Based on the description of some examples of pedagogical practices, the authors claimed that modelling helps in the development of mathematical language and tools and promotes the asking and answering of mathematical questions. Promoting the learning of mathematics is clearly an objective of pedagogical practices in mathematics classrooms. However, probably some research was necessary to support the assertions made by the authors. The concept

\footnotetext{
${ }^{1}$ The journal is published in Portuguese and is available at https://periodicos.ufsc.br/index.php/ revemat/issue/view/2153.
} 
of "learning", for example, can be understood in different ways, according to different theoretical frameworks. Swan et al. (2007) probably based their remarks in evidence from empirical studies to make their assertions about the development of mathematical language and tools and the promotion of questioning. Finally, they were supposed to relate the described competencies with the learning of mathematics, since the objective of the chapter was the promotion of learning of mathematics. All these procedures are proper for the development of research.

My main interest in the research studies being developed in the field of modelling in mathematics education comes when a pedagogical practice is specially created for the conducting of a research study, as was done by Maßß (2010). Maaß integrated six modelling units into the teaching of mathematics classes for two parallel classes (13-14 years old) over a 15 month period, being both their teacher and researcher. This is also the case in the research developed by myself and in the ones developed by my masters and doctorate students, which evoked the need for methodological reflections on the conducting of our own research (Araújo et al. 2012, 2015; Campos and Araújo 2015). Undertaking reflections on the act of researching is a desirable practice when one adopts a socio-political perspective in mathematics education, as is the case in our group:

\begin{abstract}
A socio-political perspective in mathematics education does not only offer possible theoretical tools and interpretations, but also emphasises the researcher's awareness of the research process and on how he/she privileges - and silences - diverse aspects of the research activity. In this sense, examining the process of research and its elements - and evidencing the power relationships involved in them - becomes one of the central features of socio-political approaches in mathematics education research. (Valero and Zevenbergen 2004, p. 3)
\end{abstract}

Considering the co-existence of pedagogical practice (sometimes specially created for the conducting of the study) and research in the young field of modelling in mathematics education and the socio-political perspective in mathematics education assumed by us, my objective in writing this chapter is to describe the current state of the reflections carried out by ourselves, with the aim of designing a framework for understanding the dialectical relationship between pedagogical practice and research, which I represent as pedagogical practicelresearch. ${ }^{2}$

When a pedagogical practice is taking place at the same time that a research study is, the researcher can have a double role, as a researcher and as a teacher, and the participants of the research can also have the role of students, in that pedagogical practice.

In the next sections, I will present the main elements of the pedagogical practicelresearch dialectic clarifying the concept, and discuss how the relationships

\footnotetext{
${ }^{2}$ I have represented this dialectic by a vertical bar between its two components. The symbol "l" used in the expression is called the Sheffer stroke. Any expression plq is true if and only if not both $p$ and $\mathrm{q}$ are true. "In other words, the total expression is true only if it contains a contradiction. In a materialist dialectical approach, such inner contradictions [...] represent cultural-historical processes and entities and, in fact, constitute the driving forces underlying individuallcultural development." (Roth 2005, p. xviii, emphasis in the original). In my use of the symbol, I mean that in a pedagogical practicelresearch it is not true that only a pedagogical practice is happening nor is it true that only a research is happening.
} 
between the teacher|researcher and the student|participant can be described and understood by means of this dialectic. Some examples of studies will be given to illustrate these dialectical relationships.

\subsection{Pedagogical PracticelResearch}

Before reflecting on the dialectic itself, it is important to present how I understand the two elements that it is composed of: pedagogical practice and research.

Research involves a systematic investigation supported by rigorous theoretical and methodological references, accepted by the community in which the research is taking place (see also Niss 2001). According to Bicudo (1993, p. 21), it is an "inquiring search conducted from the [research] question". The author draws attention to the importance of not confusing research with pedagogical practice. The latter is an activity that clearly aims to put people in touch with the cultural arsenal already produced by the society in which they were born. Pedagogical practice involves a subject or content, a teaching methodology, materials, some theoretical perspective guiding the development of the practice and of course, the teacher and the students. Therefore, research and pedagogical practice are two different activities; they have different purposes and are organised in different ways.

The pedagogical practices where I normally conduct research involve modelling activities guided by critical mathematics education (Alrø et al. 2010; Skovsmose 2005). These practices can be classified in the socio-critical perspective of modelling in mathematics education (Kaiser and Sriraman 2006). In these practices, students are invited to use mathematics to investigate situations with reference to reality and, at the same time, to reflect on (and to question) how mathematics is used as a tool and language of power (Araújo 2007; Barbosa 2006). Such pedagogical practices ask for "not only mathematical (conceptual) understanding, but also contextual knowledge, political awareness and judgements based on values" (Jablonka 2007 , p. 197). The intention is not only to develop mathematical calculus skills, but also to promote the critical participation of students/citizens in society, discussing the political, economic, environmental issues, etcetera, in which mathematics serves as a form of technological support. Pedagogical practices of mathematical modelling guided by critical mathematics education play an important role in the socio-political perspective in mathematics education because of its ties to the students' everyday lives, their experiences, their places in society with all its political, economic and environmental conditions.

It is important that the methodological approach of research is in harmony with its theoretical guidelines. In this sense, my studies are based on a critical research paradigm that, according to Skovsmose and Borba (2004), makes use of procedures that go beyond the observation and recording of situations that actually happened. For these authors, "doing critical research also means to explore what is not there and what is not actual", which implies an investigation into "what could be. Critical research pays special attention to hypothetical situations, although still considering 
what is actual. Critical research investigates alternatives" (p. 211, emphasis in the original). The authors claim that critical research should encompass a mixture of proper research and activities of educational development. They give an example of a researcher being engaged in a development project, working together with a teacher. They worked co-operatively and developed a research study and a pedagogical practice (the activity of educational development) at the same time.

In other words, the main reason for the creation of a pedagogical practice to conduct the research is not the absence or scarcity of contexts in which to do it, but the intention to provoke "the critique and the transformation of the social, political, cultural, economic, ethnic, and gender structures that constrain and exploit humankind, by engagement in confrontation, even conflict" (Guba and Lincoln 1994, p. 113, emphasis in the original). Mathematical modelling guided by critical mathematics education can be a feasible way to put these ideas into practice, which is illustrated in the following example.

\subsubsection{An Example}

The development of modelling projects guided by critical mathematics education is not common in day-to-day mathematics classes at the university where I am a teacher. Pedagogical practices there are characterised by the common practice of mathematics classes in higher education, with lectures, exercises and tests. This educational context, existing prior to the research, is what Skovsmose and Borba (2004) call the current situation (CS).

In fact, this is the current situation in most mathematics classrooms. According to Pais (2010, p. 134), "in school life an environment of criticism and questioning is absent. The teacher has a mission consisting of transmitting [to the students] a particular body of knowledge". However, "the relationship between the mathematical knowledge that is expected to be developed by teachers and students in classrooms and the knowledge developed and used in other mathematical practices" (Jablonka 2010 , p. 89) is something that we should be concerned with. Such ideas, based on critical mathematics education, help to ground a critique of the current situation, seeking to transform it, taking into account an imagined situation (IS) (Skovsmose and Borba 2004, p. 213), in which modelling pedagogical practices guided by critical mathematics education would be part of mathematics classes at university. Imagined situations are "vision about the possibilities of alternatives" to the current situation.

Up to this point in the example, I have spoken of two pedagogical practices: both the current and the imagined situations describe activities involving (or that would involve) teachers and students, a discipline (mathematics), teaching methods, and a theoretical perspective influencing (or that would influence) each one. In my case, the process of critiquing the current situation while envisioning an imagined situation is strongly linked to the development of research. This is a characteristic of the pedagogical practicelresearch dialectic. 
A research study developed by myself (Araújo 2013) aimed to characterise and analyse students' learning (understood according to a specific theoretical framework) while developing modelling projects guided by critical mathematics education. Two components in the description of the objective of the research can be highlighted: (i) the modelling projects guided by critical mathematics education, that are the pedagogical practice, the context of the research; and (ii) the characterisation and analysis of students' learning within this context, which is the objective of the research.

Since this intended context for the research does not exist in the current situation at the university, and as the result of a critique of this situation, it would be necessary to pursue the imagined situation. However, imagining alternatives to a current situation does not necessarily mean that they will be implemented in the way we imagined. I therefore invited former students of mine to participate voluntarily in the research study, developing a modelling project outside the context of formal university courses, which gave rise to what Skovsmose and Borba (2004, p. 214) call an arranged situation (AS): a "practical alternative that emerges from a negotiation involving the researchers and teachers" as well as students. "The arranged situation may be limited by different kinds of structural and practical constraints. But it has been arranged with the imagined situation in mind".

Five students, coming from three different courses within the Exact Sciences area, accepted the invitation to participate in the research: Alberto, from the Systems Engineering course; Pedro and Rafael, from the Physics course; Natália and Débora, ${ }^{3}$ from the Mathematics course. In addition, three researchers also participated in the meetings to develop the research: Jussara Araújo (researcher in charge), Ana Paula Rocha and Ilaine Campos (assistant researchers and, at the time, Masters students in education, supervised by myself). The development of the research occurred over nine meetings from October 2012 to June 2013. This group of eight people worked on the modelling learning project, guided by issues of critical mathematical education, which constituted the pedagogical practice in which the research was carried out.

The theme of the modelling project developed by the group was the purchase of property (real estate). It was chosen by the five students, members of the group. After they had chosen the theme, they delimited the objective of the project, which was to establish a ranking of the factors that might influence choice when purchasing property. To achieve this objective, the group designed a questionnaire, which included more demographic questions, referring to name, city in which the person resides, civil status, etcetera; and questions related to the importance that the person attached to living close to hospitals, schools, city centre, workplace, leisure areas; importance of the financial value of the property; and easy payment methods for the acquisition of the property, among others. The questionnaire was conducted with 163 people and, after receiving the responses, the group constructed a mathematical model to assign a degree of relevance to each of the factors that were included in the questionnaire and then, to establish a ranking of these factors.

Before describing the research, observations about the pedagogical practice is pertinent. The purchase of property is not necessarily a theme that would provoke the

\footnotetext{
${ }^{3}$ The names of the participants of the research are fictitious.
} 
emergence of ideas of critical mathematics education. Then, to carry out my plans as researcher, I had to make these ideas arise from the discussion along with the pedagogical practice. Since the pedagogical practice was taking place in an arranged situation, with a small group of students and with the help of two assistant researchers, it was possible for us to be attentive and stimulate critical mathematical education discussion throughout the pedagogical practice. In others words, critical themes do not belong necessarily to the day-to-day mathematics classes at the university so it was necessary to stimulate them. This is an insight that has arisen from the pedagogical practice being integrated into the arranged situation.

To develop the research, which had this pedagogical practice as context, three different methodological procedures were adopted: Firstly, participant observations (Adler and Adler 1994) were used as the researchers acted and intervened throughout the modelling project created for the development of the research. These observations were recorded through field notes and filming. Secondly, a record of the activities was kept in an online text editor. The research participants were asked to register the development reports of the project in a shared document-which both researchers and participants had access to-stored by the application package Google Drive (2017), a file storage and synchronization service, developed by Google. This way, the participation in the research could happen in person or virtually, in the virtual space created for the group. Thirdly, interviews, both individually and as collectives, were conducted by me to build deeper insights into the episodes created from the videos (the first procedure) or into the report produced online (the second procedure). The interviews were semi-structured (Fontana and Frey 1994), since there were some questions previously planned, but several others were elaborated according to the progress of the interview. The recording of the interviews was also done through filming.

Although the intention was to do modelling grounded in the ideas of critical mathematics education, Araújo et al. (2014) concluded that, according to a proposal made by Rafael (a participant of the research study), the role of mathematical models was to make predictions about the future, more accurately, with fewer mistakes. However, such a proposal was in conflict with the ideas of critical mathematics education. Thus, an analysis of data gathered for the research study shed more light on conceptions of mathematics rooted in the school mathematics tradition (Skovsmose 2005), which are questioned by critical mathematics education. Based on our study, we were able to conclude that having the intention to develop modelling guided by critical mathematics education is not sufficient to do so and, thus, the research study carried out in the pedagogical practice gave new insights into the current situation.

The descriptions of the pedagogical practice and of the research highlight two sets of procedures, one set corresponding to each practice, which, however, occurred simultaneously:

- Pedagogical practice: choice of a theme for the modelling project; definition of the objective of the project; searching for information; elaboration of a questionnaire; data collection; building model(s); seeking solutions. 
- Research: participant observations recorded by field notes and filming; a record of the activities in an online text editor; collective or individual interviews, recorded on film.

With regard to these procedures, we had to be very clear about the differences and relationships between pedagogical practice and research (Bicudo 1993), in order not to state that a pedagogical procedure is a research procedure, or vice versa. In fact, we had to be very clear the whole time, since the relationship and mutual influence between these two practices were present from the beginning, as can be seen in the previous description.

As I have explained in the introduction to this chapter, we have used a vertical bar to represent the pedagogical practicelresearch dialectic (Araújo et al. 2012, 2015). Goulart and Roth (2006) use this notation to represent the dialectical union between margin and centre (marginlcentre), which was used to describe the participation of children in science education activities. According to these authors, this participation may be marginal or central to the activity planned and proposed by the teacher. However, Goulart and Roth (2006, p. 682) argue that the margin and centre are "two mutually presupposing but incompatible aspects of the same unit of analysis". These ideas fit nicely into the way I and my colleagues understand the relationship between pedagogical practice and research: "they are part of a single unit, mutually developing and influencing each other. They are different, have different purposes, and may be incompatible, but one presupposes and constitutes the other" (Araújo et al. 2012, p. 10).

The pedagogical practice and the research, evolving dialectically, can give new insights into the current situation, offering new inspirations for the imagined situation, and, at the same time, giving rise to new research questions, since "dialectics deals with systems in movement through time. The elements of a dialectical contradiction relate to each other within the moving structure, historically" (Engeström and Sannino 2011, p. 370).

To this point, I can summarize three characteristics of the dialectical relationship between pedagogical practice and research:

- The process of critiquing the current situation while envisioning an imagined situation is strongly linked to the development of research.

- Pedagogical procedures are different from research procedures; however, the relationship and mutual influence between pedagogical practice and research are very tight.

- The pedagogical practice and the research, evolving dialectically, can give new insights into the current situation, offering new inspirations for the imagined situation, and, at the same time, giving rise to new research questions.

I have focused my attention, particularly, on the people involved in the pedagogical practicelresearch dialectic: the teacherlresearcher and the students/participants, as I describe in the following two sections. 


\subsection{Teacher|Researcher}

When pedagogical practice and research occur in a dialectical relationship, the researcher may also be acting as a teacher, giving rise to the teacherlresearcher dialectic (Campos and Araújo 2015). This dialectic can be described based on the Masters research conducted by Campos (2013). Her focus was the involvement of the students (the participants of the research) in a modelling activity which aimed to relate students' involvement in the modelling activity to their life experiences and expectations for the future.

I was the supervisor for Campos' study and the research was conducted in a discipline taught by myself, in which modelling projects guided by critical mathematics education were developed, in a way similar to that described in the previous section. The participants of the research were two groups of students of the discipline while they developed their modelling projects. Therefore, Campos and Araújo (2015) reconsidered data from the research carried out by Campos (2013) in the context of the modelling project (i.e., the pedagogical practice) developed by one of these groups. This group was composed of seven students: Amanda, Carlos, Catarina, Eduardo, Emanuel, Fernanda and Rodrigo. ${ }^{4}$

Brazil is a federal republic formed of 26 states plus the Federal District, and Minas Gerais is one of the states. The theme of the modelling project developed by the group was "The Public-Private Partnership (PPP) in the Brazilian prison system in the State of Minas Gerais". A PPP is a set of activities performed in a shared way by the State and the private sector, for the development of services of the public sector. The objective of the group's modelling project was to calculate how much the State would cease to spend within the prison system if it was to establish a PPP.

Campos and Araújo (2015) rely on four aspects to characterise the teacherlresearcher dialectic. These will now be outlined.

\subsubsection{Aspect 1: From Researcher to Teacher}

During one of the group meetings to develop the project, the researcher asked the group questions regarding their motives for choosing the theme of the modelling project and forming groups. These questions were closely related to the objective of the research of Campos (2013). One of her questions was: "Carlos has proposed the theme; then, you were joining because you would work with people with whom you have already developed other works, and, therefore, have greater affinity?" (Campos and Araújo 2015, p. 331). Carlos showed that he had understood her purpose as a researcher by saying that the objective of the research would be, then, the motivation of the group. However, the researcher is also a mathematics teacher, and in making contact with the information that the group had, regarding its modelling project, exposed this side by asking, "How will mathematics be linked here?" (p. 332) and

\footnotetext{
${ }^{4}$ The names of the participants of the research are fictitious.
} 
went on guiding the group in the development of the project. In Campos and Araújo's analysis (2015, p. 332),

Initially, the researcher was acting and, spontaneously, on impulse, the teacher came on the scene. That is, at that moment, it happened a change of roles in the actions of the researcherlteacher [from researcher to teacher]. However, this was only possible due to her actions as a researcher, since her initial questions provided greater insights on the theme of the modelling project.

\subsubsection{Aspect 2: Research Participants Are Students, so the Researcher Is the Teacher}

The participants of the research, who were students and knew that the researcher was a mathematics teacher, spontaneously requested that she assume this role to guide them in the development of the modelling project. A dialogue involving two participants and the researcher illustrates this situation. Emanuel, addressing the researcher, stated: "So, if we do it like this, you can help us. I think you get the idea, right?" (Campos and Araújo 2015, p. 333). The researcher answered affirmatively and Fernanda stated, immediately: "Ah! So let's speed it up here. What variable will we work on then?" (Campos and Araújo 2015, p. 333). Here, the students induced and encouraged the researcher to act as a teacher.

\subsubsection{Aspect 3: The Teacher Acts on Her Own Initiative}

The group had difficulties with the mathematical content and could not move forward in the mathematical modelling. Faced with the group's lack of progress, the teacher decided to help them, guiding them in the construction of the model, as, for example, when she said: "So, this seventy will be multiplied by the coefficient that we'll call $C$ [she wrote it down in the notebook]." (Campos and Araújo 2015, p. 334). Carlos made a comment about this: "This is the most difficult in math: making the formula, to represent the data, put the bracket, seventy. This is too hard! The $C$ cannot be negative, is it right?" (Campos and Araújo 2015, p. 334).

Therefore, in some moments, the teacher acted on her own initiative and put in the background her role of researcher. Thus, "the demands [of the] modelling environment and the researcherlteacher's formation led her to act as a mathematics teacher" (Campos and Araújo 2015, p. 335). 


\subsubsection{Aspect 4: The Teacher's Reflections Favouring the Performance of the Researcher}

Having faced the difficulties that the students were having with mathematics, the researcher realised that each member of the group was involved with the modelling project in a different way, depending on his/her familiarity with mathematics. At this moment, it is important to remember that the objective of the research was to relate the involvement of the students in the modelling project with their life experiences and expectations for the future. The experience as the teacher and her researcher's reflections led her to devise new interview questions: "The activity had several moments, okay? Specifically, about the time dedicated to putting the ideas into mathematical terms, how do you analyse your relationship with math and your involvement?" (Campos and Araújo 2015, p. 335). In other words, the typical actions of a researcher "were planned and guided under the influence of her actions as a teacher in the context of the research" (p. 335).

In the end, from the analysis of these four aspects, Campos and Araújo (2015) concluded that the teacherlresearcher could be described by an alternating between the roles of the teacher and the researcher, in which one always influences and is influenced by the other, in a dialectical way. Therefore, when pedagogical practice and research occur in a dialectical relationship, the teacher|researcher acts sometimes as a teacher and at other times as a researcher, and each role is highlighted or put aside according to the necessities of the development of the pedagogical practicelresearch.

\subsection{Students|Participants}

The role of the participants, throughout research, is influenced by the relationship established between them and the researcher (Bogdan and Biklen 1994). From the study of Campos and Araújo (2015), we can see that the teacherlresearcher is constituted as a result of her relationship with the participants, who, at that time, were also students developing a modelling activity. It makes sense then, to talk about the students/participants dialectic. I start characterising the students/participants dialectic from an interpretation of each one of the four aspects described in the previous section, now focusing on the role of the students/participants of the pedagogical practicelresearch. The four aspects may be rewritten from the point of view of studentslparticipants in the following way:

- When the researcher started to act as a teacher, the participants began to act as students;

- The researcher is a teacher, so the research participants are students;

- If the teacher acted on her own initiative, then the students, who needed to develop the modelling project, took the opportunity to receive guidance;

- Because they behaved as students, revealing their low familiarity with mathematics, the participants provided information relevant to the researcher. 
Thus, the first characteristic of the dialectic is that the students/participants are constituted in relation to the teacher|researcher.

In light of these reflections, and because of my experience, another point that should be considered is the ethical care that the teacherlresearcher must take with the students/participants. Pedagogical practice and research, when each one occurs in isolation, already have their own rules to ensure the ethical care with students and the research participants, respectively. However, when we consider the pedagogical practicelresearch dialectic, new questions concerning ethical care may arise. Some issues such as ensuring rigorous data collection procedures, in the research, combined with others of pedagogical practice, such as ensuring high quality mathematical education, can give rise to conflicts, which the teacher|researcher must think and make decisions about in the heat of the moment during the pedagogical practicelresearch.

In the research described by Campos and Araújo (2015), for example, when the teacher acted on her own initiative (Aspect 3), perhaps the ethical care as a teacher has been dominant in order for her to ensure the students' learning and success in the development of the modelling project. Another example comes from a previous study (Araújo et al. 2010), in which I was a teacher and a researcher at the same time. In that study, while students developed a mathematical modelling project, I collected data for the research. When analysing the data, I realised that the methodological procedures of the research were less apparent than those of the pedagogical practice. For ethical reasons I should have focused on acting as the teacher at that time.

It is worth noting, however, that the predominance of the role of the teacher in the teacher|researcher dialectic in relation to the researcher, for ethical reasons, does not mean that the research will be hampered, due to a possible relaxation of the methodological rigour. As described by Campos and Araújo (2015), the teacher|researcher, by acting as teacher, led new insights for the researcher, requiring a reorganization of the methodological procedures, which is typical of the socio-political perspective of research in mathematics education. Thus, a second characteristic of this dialectic is that the ethical concerns regarding the students/participants help to constitute the methodological rigour of the research, which in turn, is related to the educational quality of the pedagogical practice.

\subsection{Final Remarks}

In this chapter, I sought to present the initial design of a framework for a dialectical relationship between pedagogical practice and research in the field of modelling in mathematics education, guided by the ideas of critical mathematics education, as well as some characteristics of the people involved in these practices: the teacherlresearcher and the studentslparticipants. The framework is being designed by means of my participation as a member, both locally and internationally, of the community of modelling in mathematics education and as I become more experienced as a researcher and advisor of master and doctorate students. In the chapter, I based my argument mainly in two examples of such research studies. 
I understand that this discussion is important not only for the socio-critical perspective of modelling in mathematics education, but also for the other perspectives. As discussed in the Introduction to this chapter, modelling in mathematics education is a relatively young research field that is experiencing a maturation phase. Thus, it is important that our community looks at the corpus of research studies undertaken in order to organize them and to understand characteristics of practices that have been legitimized by this community (see Galbraith 2013).

One of these practices is the simultaneous occurrence of pedagogical practice and research. In literature, there is work, for example, in which procedures that are proper to pedagogical practices are mistakenly called research procedures and vice versa. The research field needs to have a clear distinction between these two practices. In this chapter, I sought to go forward in this direction.

In the specific case of modelling guided by critical mathematics education, "examining the process of research and its elements" (Valero and Zevenbergen 2004, p. 3) is paramount, since this is desirable in a socio-political approach in mathematics education. Having the objective of critiquing and transforming the social structures that constrain and exploit humankind, research studies about modelling according to critical mathematics education are being developed in pedagogical practices specially created for this purpose. The socio-critical perspective in mathematics education is rooted in transforming mathematics pedagogical practice by taking into account all of the student's background and foreground, and by guiding the students to become independent decision makers and critical users of (mathematical) information. Mathematical modelling, because of its ties to the real world, strongly depends on the situation of the students, in comparison to other parts of mathematical education. These characteristics reinforce the necessity of being very clear about the proper procedures of each-pedagogical practice and research - since there are objectives of different natures to be reached.

As I stated at the outset, the ideas presented here are initial steps towards the framework. Further studies, reflections and examples are needed for a greater maturity of this framework and I hope that our community of modelling in mathematics education feels encouraged to join me in this challenge.

Acknowledgements I would like to thank the editors of the book and the reviewers of the chapter for critiques and suggestions to a previous version of this chapter. The research project developed by Araújo (2013) had the financial support of the "Conselho Nacional de Desenvolvimento Científico e Tecnológico" (CNPq, Process no. 473850/2011-7) and the "Fundação de Amparo à Pesquisa do Estado de Minas Gerais” (FAPEMIG, Process no. 00235/13), funding agencies in Brazil. 


\section{References}

Adler, P. A., \& Adler, P. (1994). Observational techniques. In N. K. Denzin \& Y. S. Lincoln (Eds.), Handbook of qualitative research (pp. 377-392). Thousand Oaks, CA: Sage.

Albarracín, L., \& Gorgorió, N. (2015). A brief guide to modelling in secondary school: Estimating big numbers. Teaching Mathematics and Its Applications, 34(4), 223-228. https://doi.org/10. 1093/teamat/hrv006.

Alrø, H., Ravn, O., \& Valero, P. (Eds.). (2010). Critical mathematics education: Past, present and future. Rotterdam, The Netherlands: Sense.

Araújo, J. L. (2007). Modelling and the critical use of mathematics. In C. Haines, P. Galbraith, W. Blum, \& S. Khan (Eds.). Mathematical modelling: Education, engineering and economics (ICTMA 12) (pp. 187-194). Chichester: Horwood.

Araújo, J. L. (2013). Aprendizagem expansiva em projetos de modelagem orientados pela educação matemática crítica. Research project. Belo Horizonte: Department of Mathematics at the Federal University of Minas Gerais (UFMG).

Araújo, J. L., Campos, I. S., \& Camelo, F. B. (2015). A dialectal interpretation of the relationship between teaching practice and research according to critical mathematics education. In B. S. D'Ambrosio \& C. E. Lopes (Eds.), Creative insubordination in Brazilian mathematics education research (pp. 69-80). Raleigh: Lulu Press.

Araújo, J. L., Campos, I. S., \& Freitas, W. S. (2012). Prática pedagógica e pesquisa em modelagem na educação matemática. In Proceedings of 5th Seminário Internacional de Pesquisa em Educação Matemática. Petrópolis, Brazil: Sociedade Brasileira de Educação Matemática. 1 CD-ROM.

Araújo, J. L., Rocha, A. P. F. P., \& Martins, D. A. (2014). Papel da matemática (ou de modelos matemáticos) em ambientes de modelagem: A proposta de Rafael. REMATEC: Revista de Matemática Ensino e Cultura, 17, 5-23.

Araújo, J. L., Santos, M., \& Silva, T. (2010). Tracking object(s) in mathematical modelling activity(ies). In M. M. F. Pinto \& T. F. Kawasaki (Eds.), Proceedings of 34th Conference of the International Group for the Psychology of Mathematics Education (Vol. 2, pp. 161-168). Belo Horizonte, Brazil: PME.

Barbosa, J. C. (2006). Mathematical modelling in the classroom: The socio critical and discursive perspective. ZDM Mathematics Education, 38(3), 293-301.

Blum, W., Galbraith, P. L., Henn, H.-W., \& Niss, M. (Eds.). (2007). Modelling and applications in mathematics education: The 14th ICMI study. New York: Springer.

Bicudo, M. A. V. (1993). Pesquisa em educação matemática. Pro-posições, 4(1), 18-23.

Bogdan, R., \& Biklen, S. (1994). Investigação qualitativa em educação: Uma introdução à teoria e aos métodos. Porto: Porto Editora.

Campos, I. S. (2013). Alunos em ambientes de modelagem matemática: Caracterização do envolvimento a partir da relação com o background e o foreground. Unpublished Master dissertation, Universidade Federal de Minas Gerais, Belo Horizonte, MG, Brasil.

Campos, I. S., \& Araújo, J. L. (2015). Quando pesquisa e prática pedagógica acontecem simultaneamente no ambiente de modelagem matemática: Problematizando a dialética pesquisadorlprofessor. Acta Scientiae, 17(2), 324-339. http://www.periodicos.ulbra.br/index. php/acta/article/view/1425/1202. Accessed July 02, 2017.

Engeström, Y., \& Sannino, A. (2011). Discursive manifestations of contradictions in organizational change efforts: A methodological framework. Journal of Organizations Change Management, 24(3), 368-387. https://doi.org/10.1108/09534811111132758.

Fontana, A., \& Frey, J. H. (1994). Interviewing: The art of science. In N. K. Denzin \& Y. S. Lincoln (Eds.), Handbook of qualitative research (pp. 361-376). Thousand Oaks, CA: Sage.

Galbraith, P. (2013). From conference to community: An ICTMA journey-The Ken Houston inaugural lecture. In G. A. Stillman, G. Kaiser, W. Blum, \& J. P. Brown (Eds.), Teaching mathematical modelling: Connecting to research and practice (pp. 27-45). Dordrecht: Springer.

Geiger, V., \& Frejd, P. (2015). A reflection on mathematical modelling and applications as a field of research: Theoretical orientation and diversity. In G. A. Stillman, W. Blum, \& M. S. Biem- 
bengut (Eds.), Mathematical modelling in educational research and practice: Cultural, social and cognitive influences (pp. 161-171). Cham: Springer.

Google Drive. (2017). https://en.wikipedia.org/wiki/Google_Drive. Accessed July 01, 2017.

Goulart, M. I. M., \& Roth, W.-M. (2006). Marginlcentre: Toward a dialectic view of participation. Journal of Curriculum Studies, 38(6), 679-700.

Guba, E. G., \& Lincoln, Y. S. (1994). Competing paradigms in qualitative research. In N. K. Denzin \& Y. S. Lincoln (Eds.), Handbook of qualitative research (pp. 105-117). Thousand Oaks, CA: Sage.

Jablonka, E. (2007). The relevance of modelling and applications: Relevant to whom and for what purpose? In W. Blum, P. L. Galbraith, H.-W. Henn, \& M. Niss (Eds.), Modelling and applications in mathematics education: The 14th ICMI study (pp. 193-200). New York: Springer.

Jablonka, E. (2010). Reflections on mathematical modelling. In H. Alrø, O. Ravn, \& P. Valero (Eds.), Critical mathematics education: Past, present and future (pp. 89-100). Rotterdam, The Netherlands: Sense.

Kaiser, G., \& Sriraman, B. (2006). A global survey of international perspectives on modelling in mathematics education. ZDM Mathematics Education, 38(3), 302-310.

Maaß, K. (2010). Modeling in class and the development of beliefs about the usefulness of mathematics. In R. Lesh, P. L. Galbraith, C. R. Haines, \& A. Hurford (Eds.), Modeling students' mathematical modeling competencies (pp. 409-420). New York: Springer.

Niss, M. (2001). Issues and problems of research on the teaching and learning of applications and modelling. In J. F. Matos, W. Blum, S. K. Houston, \& S. P. Carriers (Eds.), Modelling and mathematics education (pp. 72-88). Chichester: Horwood.

Niss, M., Blum, W., \& Galbraith, P. L. (2007). Introduction. In W. Blum, P. L. Galbraith, H.-W. Henn, \& M. Niss (Eds.), Modelling and applications in mathematics education: The 14th ICMI study (pp. 3-32). New York: Springer.

Pais, A. (2010). Portrait of an influence. In H. Alrø, O. Ravn, \& P. Valero (Eds.), Critical mathematics education: Past, present and future (pp. 133-144). Rotterdam, The Netherlands: Sense.

Roth, W.-M. (2005). Introduction. Doing qualitative research: Praxis of method (pp. i-xviii). Rotterdam: The Netherlands: Sense.

Schwarzkopf, R. (2007). Elementary modelling in mathematics lessons: The interplay between "real-world" knowledge and "mathematical structures". In W. Blum, P. L. Galbraith, H.-W. Henn, \& M. Niss (Eds.), Modelling and applications in mathematics education: The 14th ICMI study (pp. 209-216). New York: Springer.

Skovsmose, O. (2005). Travelling through education: Uncertainty, mathematics, responsibility. Rotterdam: The Netherlands: Sense.

Skovsmose, O., \& Borba, M. C. (2004). Research methodology and critical mathematics education. In P. Valero \& R. Zevenbergen (Eds.), Researching the socio-political dimensions of mathematics education (pp. 207-226). Dordrecht: Kluwer Academic.

Swan, M., Turner, R., \& Yoon, C. (2007). The roles of modelling in learning mathematics. In W. Blum, P. L. Galbraith, H.-W. Henn, \& M. Niss (Eds.), Modelling and applications in mathematics education: The 14th ICMI study (pp. 275-284). New York: Springer.

Valero, P., \& Zevenbergen, R. (2004). Introduction. In P. Valero \& R. Zevenbergen (Eds.), Researching the socio-political dimensions of mathematics education (pp. 1-4). Dordrecht: Kluwer Academic.

Villarreal, M. E., Esteley, C. B., \& Smith, S. (2015). Pre-service mathematics teachers' experiences in modelling projects from a socio-critical modelling perspective. In G. A. Stillman, W. Blum, \& M. S. Biembengut (Eds.), Mathematical modelling in educational research and practice: Cultural, social and cognitive influences (pp. 567-578). Cham: Springer. 
Open Access This chapter is licensed under the terms of the Creative Commons Attribution 4.0 International License (http://creativecommons.org/licenses/by/4.0/), which permits use, sharing, adaptation, distribution and reproduction in any medium or format, as long as you give appropriate credit to the original author(s) and the source, provide a link to the Creative Commons license and indicate if changes were made.

The images or other third party material in this chapter are included in the chapter's Creative Commons license, unless indicated otherwise in a credit line to the material. If material is not included in the chapter's Creative Commons license and your intended use is not permitted by statutory regulation or exceeds the permitted use, you will need to obtain permission directly from the copyright holder.

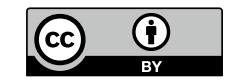

